\title{
Perancangan Sistem Pengukuran Kerja dengan Metode Intergrated Performance Measurement System (IPMS) (Studi Kasus: CV. Ekasari)
}

\author{
Indah Kurniyati $^{1)}$, Risya Zeline ${ }^{2)}$, Sri Yohana Simanjuntak ${ }^{3)}$, Yuniaristanto ${ }^{4)}$ \\ ${ }^{1,2,3)}$ Mahasiswa Program Studi Teknik Industri, Fakultas Teknik, Universitas Sebelas Maret Jl.Ir. Sutami \\ 36A Surakarta 57126 Indonesia \\ ${ }^{4)}$ Dosen Program Studi Teknik Industri, Fakultas Teknik, Universitas Sebelas Maret \\ Jl.Ir. Sutami 36A Surakarta 57126 Indonesia
}

\begin{abstract}
Global business competition greatly increased sharply in Indonesia, including in the food market. To succeed and grow in the competition, an organization should use measurement and management systems derived from the strategies and capabilities of the company. CV. Eka Sari is a company engaged in the field of catering, where business activity in CV. Eka Sari is more focused on providing the bread and cakes. The continued development of the catering business, demanding CV. Eka Sari to improve in every aspects of company performance, so that the company can remain competitive with other companies. Therefore, CV. Eka Sari is in need of performance measurement that aims to evaluate and plan its performance in order to achieve organizational goals. Performance measurement methods used by the company is Integrated Performance Measurement System (IPMS), which is a method that measures the performance of an integrated and based on the wishes of stakeholders. Objectives are determined to meet the wishes of stakeholders, so that will be determined key performance indicators. From the results of the identification, obtained 22 key performance indicators. To determine the performance criteria that need more attention then be weighted. Weighting is done using Hierachy Analytical Process (AHP). Weighting results generated from that aspect that must be considered are aspects of the process, then the performance criteria that must be considered, namely improving the efficiency and effectiveness of production, and Key Performance Indicators to be very aware of is the number of defective products.
\end{abstract}

Keywords : Analytical Hierarchy Process, Integrated Performance Measurement Systems, Key Performance Indicators, Performance Measurement

\section{Pendahuluan}

Persaingan usaha global sangat meningkat tajam di Indonesia, tidak terkecuali dalam pasar makanan. Untuk berhasil dan tumbuh dalam persaingan usaha, suatu organisasi harus menggunakan sistem pengukuran dan manajemen yang diturunkan dari strategi dan kapabilitas yang dimiliki perusahaan. Pengukuran kinerja dalam sebuah organisasi merupakan suatu hal yang sangat penting untuk dilakukan karena semua organisasi perlu mengevaluasi dan merencanakan kinerjanya agar dapat mencapai tujuan organisasi (Witjaksono, 2009). Edward Deming melalui model siklus PDCA-nya mengemukakan bahwa pada proses bisnis sebaiknya dilakukan analisis dan pengukuran untuk mengidentifikasi kesalahan yang terjadi dan menyebabkan produk menyimpang dari keinginan customer (Paul Averson, 1998). Tanpa pengukuran kinerja, proses untuk mencapai tujuan tidak dapat di manage sehingga tujuan perusahaan tidak dapat tercapai. Pengukuran kinerja juga diperlukan untuk melaporkan kondisi perusahaan kepada pihak stakeholder perusahaan (Yasrin Zabidi, 2008).

$\mathrm{CV}$. Eka Sari merupakan perusahaan yang bergerak di bidang katering, dimana kegiatan usaha di CV. Eka Sari ini lebih fokus pada penyediaan roti dan kue. Katering adalah kegiatan usaha yang menyediakan makan dan pelayanan (Bode, 2003). Semakin berkembangnya bisnis katering, menuntut CV. Eka Sari untuk berbenah dalam setiap aspek-aspek kinerja perusahaannya, sehingga perusahaan dapat tetap bersaing dengan perusahaan lain. Upaya untuk dapat tetap besaingan dalam lingkungan bisnisnya yaitu dengan mengetahui tingkat performansi perusahaan dengan melakukan pengukuran kinerja. Pengukuran kinerja dilakukan karena pada

\footnotetext{
*Correspondance: indahkurniyati.ia2@gmail.com
} 
dasarnya semua perusahaan perlu mengevaluasi dan merencanakan kinerjanya, sehingga terjadi peningkatan proses kinerja yang ditandai dengan tercapainya tujuan akhir perusahaan, yaitu dengan adanya peningkatan profit perusahaan (Sesutyo, 2013). Oleh karena itu, CV. Eka Sari sangat memerlukan pengukuran kinerja yang bertujuan untuk mengevaluasi dan merencanakan kinerjanya agar dapat mencapai tujuan organisasi. Saat ini, persaingan usaha sangat meningkat dalam era globalisasi ini, tak terkecuali juga dalam bisnis catering dan kue di CV. Eka Sari.

Metode pengukuran kinerja yang digunakan oleh perusahaan yaitu Integrated Performance Measurement Systems (IPMS), yang merupakan suatu metode yang mengukur kinerja secara terintegrasi dan berbasis pada keinginan stakeholders. Objectives ditentukan untuk memenuhi keinginan stakeholders, sehingga akan dapat ditentukan key performance indicators (Witjaksono, 2009). Proses perancangan sistem pengukuran kinerja dilakukan secara top-down atau dari jenjang manajemen teratas atau level bisnis ke seluruh aktivitas yang ada, yang memperhatikan kebutuhan-kebutuhan dari setiap stakeholders (stakeholder requirements), dan tetap memonitor posisi perusahaan terhadap pesaingnya (external monitor). IPMS dapat diterapkan pada perusahaan yang berorientasi untuk mendapatkan profit secara optimal, maupun pada organisasi non profit.

\section{Metode Penelitian}

Penelitian ini diawali dengan identifikasi masalah di CV. Eka Sari Katering menggunakan metode observasi secara langsung. Kemudian dilakukan pengukuran kinerja dengan menggunakna metode Integrated Performance Measurement (IPMS). Integrated Performance Measurement (IPMS) adalah salah satu metode pengukuran kinerja yang bertujuan untuk menggambarkan sistem pengukuran kinerja dalam arti yang tepat, dalam bentuk integrasi, seefektif dan efisien mungkin (Winarni, 2012). Tahap awal dalam metode IPMS ini yaitu Stakeholder's Requirements yang diperoleh dengan metode wawancara. Tahap selanjutnya yaitu menentukan objective. Berdasarkan objective yang telah Key Performance Indicator (KPI). KPI yang telah dibuat kemudian divalidasi dengan KPI menggunakan kuesioner yang dibagikan kepada stakeholder di CV. Eka Sari. Kemudian dilakukan penyusunan hierarki kinerja guna membuat pembobotan KPI menggunakan metode Analytical Hieracchy Process (AHP). Menurut Bourgeois (2005) AHP umumnya digunakan dengan tujuan untuk menyusun prioritas dari berbagai alternatif/pilihan yang ada dan pilihan-pilihan tersebut bersifat kompleks atau multi kriteria. Formulasi matematis pada AHP dilakukan dengan menggunakan matriks, dimana pada akhirnya nanti hal tersebut akan membantu dalam pengambilan keputusan. Skala-sakal kuantitatif yang digunakan yaitu rentang 1 sampai 9 untuk menilai perbandingan tingkat kepentingan suatu elemen terhadap elemen lainnya. Dari hasil pembobotan tersebut diperoleh tingkat kepentingan dari masing-masing aspek tujuan stakeholder serta KPI (Susetyo, 2013).

\section{Pembahasan}

\section{Stakeholder Requirement}

Sebelum mengidentifikasi stakeholder requirement, pertama-tama dilakukan pembagian level bisnis. Berdasarkan sistem organisasi perusahaan. Level bisnis tersebut ditunjukkan pada Gambar 1.

Berdasarkan pendekatan sistem dan pembagian level organisasi dapat diketahui stakeholder CV Ekasari adalah pemilik usaha, tenaga kerja, supplier, konsumen, dan masyarakat sekitar. Dari masing-masing stakeholder tersebut kemudian diidentifikasi requirement-nya. Dari masing-masing stakeholders tersebut kemudian diidentifikasi requirement-nya. Stakeholder requirement diampilkan pada Tabel 1. 


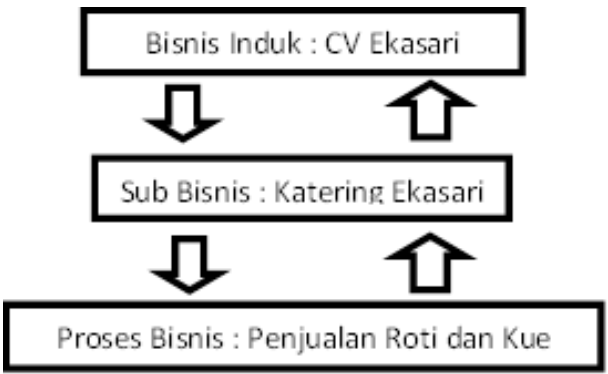

Gambar 1. Pembagian Level Organisasi CV. Ekasari

\section{Identifikasi Objective}

Objective ditetapkan berdasarkan requirement yang telah teridentifikasi untuk masingmasing stakeholder. Pada CV.Ekasari terdapat stakeholder yang meliputi pemilik usaha, tenaga kerja, pelanggan, supplier, dan masyarakat. Identifikasi objective yang dilakukan bersama dengan pihak perusahaan adalah dengan wawancara secara langsung dengan pemilik usaha dan juga berdasarkan visi misi yang dimiliki oleh perusahaan.Visi perusahaan yaitu menjadi penyedia jasa caterin yang mengedepankan kepuasan pelanggan melalui produktivitas dan pencapaian kesejahteraan karyawan. Misi perusahaan yaitu meningkatkan profesionalisme, produktivitas, dan efisiensi untuk mencapai kepuasan pelanggan, meningkatkan kedisiplinan dalam bekerja dan memberikan pelayanan yang prima, serta menyediakan makanan yang berkualitas, sehat, dan bercita rasa. Berikut adalah daftar objective yang telah diidentifikasi

Tabel 1. Hasil Identifikasi Objective

\begin{tabular}{|c|c|c|}
\hline No & Requirement & Objective \\
\hline $\begin{array}{l}1 \\
2 \\
3 \\
4 \\
5 \\
6 \\
7\end{array}$ & $\begin{array}{l}\text { Pengiriman barang tepat waktu } \\
\text { Jenis kue yang dikirimkan sesuai dengan pesanan } \\
\text { Jumlah produk yang dikirimkan sesuai pesanan } \\
\text { Kualitas produk selalu dipertahankan } \\
\text { Komplain cepat direspon } \\
\text { Meminimalkan tingkat kecacatan barang saat produksi } \\
\text { Customer baru bertambah }\end{array}$ & $\begin{array}{l}\text { - Meningkatkan kepuasan pelanggan } \\
\text { - Meningkatkan loyalitas pelanggan }\end{array}$ \\
\hline $\begin{array}{l}8 \\
9 \\
10\end{array}$ & $\begin{array}{l}\text { Adanya system informasi yang baik } \\
\text { Perbaikan sarana dan prasarana kerja } \\
\text { Sarana dan prasarana kerja memadai }\end{array}$ & $\begin{array}{l}\text { - Meningkatkan kualitas system informasi } \\
\text { manajemen } \\
\text { - Meningkatkan kenyamanan bekerja para pekerja }\end{array}$ \\
\hline 11 & Perawatan mesin produksi yang teratur & - Mengurangi tingkat kerusakan mesin \\
\hline $\begin{array}{l}12 \\
13 \\
14\end{array}$ & $\begin{array}{l}\text { Keluhan pekerja lebih diperhatikan oleh perusahaan } \\
\text { Keluhan cepat ditanggapi oleh perusahaan } \\
\text { Adanya reward jika target pesanan tercapai }\end{array}$ & $\begin{array}{l}\text { - } \quad \text { Meningkatkan produktivita para pekerja } \\
\text { - } \text { Meningkatkan loyalitas para pekerja }\end{array}$ \\
\hline 15 & $\begin{array}{l}\text { Adanya kesadaran dari para pekerja untuk menjaga } \\
\text { kualitas dan kuantitas produksi } \\
\text { Adanya kesadaran dari pada pekerja untuk menjaga } \\
\text { kestabilan kualitas dan kuantitas dalam system } \\
\text { produksi } \\
\text { Setiap produksi berjalan dengan lancar }\end{array}$ & $\begin{array}{ll}\text { - } & \text { Meningkatkan efisiensi dan efektivitas produksi } \\
\text { - } & \text { Mengurangi produk cacat } \\
\text { - } & \text { Meningkatkan biaya operasional }\end{array}$ \\
\hline $\begin{array}{l}18 \\
19 \\
20\end{array}$ & $\begin{array}{l}\text { Adanya sistem laporan keuangan yang efektif } \\
\text { Transparansi laporan keuangan perusahaan } \\
\text { Adanya peningkatan keuntungan dan pendapatan } \\
\text { perusahaan }\end{array}$ & - Meningkatkan kineja keuangan \\
\hline 21 & Produk perusahaan lebih dikenal di skala nasional & $\begin{array}{l}\text { - Meningkatkan keuntungan dan pendapatan } \\
\text { perusahaan }\end{array}$ \\
\hline $\begin{array}{l}22 \\
23 \\
24 \\
25\end{array}$ & $\begin{array}{l}\text { Peningkatan jumlah order ke supplier } \\
\text { Order teratur } \\
\text { Pembayaran tepat waktu } \\
\text { Terjalin hubungan dengan perusahaan }\end{array}$ & - Meningkatkan hubungan baik dengan supplier \\
\hline $\begin{array}{l}26 \\
27 \\
28\end{array}$ & $\begin{array}{l}\text { Menjadi perusahaan yang ramah lingkungan } \\
\text { Menerima siswa SMK yang ingin melakukan PKL } \\
\text { Menerima mahasiswa yang ingin melakukan penelitian }\end{array}$ & $\begin{array}{l}\text { - Meningkatkan kepercayaan masyarakat } \\
\text { - Menjalin hubungan baik dengan masyarakat }\end{array}$ \\
\hline
\end{tabular}

\section{Identifikasi Key Performance Indicator}

Objective telah ditetapkan berdasarkan requirement yang telah terindetifikasi. Selanjutnya dilakukan pengukuran untuk masing-masing objective, dengan tujuan mengetahui tingkat pencapaian tiap-tiap objective. Cara pengukuran tingkat pencapaian objective adalah dengan 
menentukan indikator keberhasilannya, yaitu disebut dengan Key Performance Indicators (KPI). Daftar KPI yang terbentuk dari pengidentifikasian objective ditampilkan pada tabel 2.

Tabel 2. Hasil Identifikasi Key Performance Indicators

\begin{tabular}{|c|c|c|}
\hline No & Objective & Key Performance Indicator \\
\hline $1-7$ & $\begin{array}{l}\text { - Meningkatkan kepuasan pelanggan } \\
\text { - Meningkatkan loyalitas pelanggan }\end{array}$ & $\begin{array}{l}\text { 1. Rasio pengiriman produk tepat waktu } \\
\text { 2. Rasio kesalahan kuantitas pengiriman } \\
\text { 3. Jumlah komplain pelanggan } \\
\text { 4. Jumlah komplain pelanggan yang } \\
\text { diselesaikan } \\
\text { 5. Tingkat pertumbuhan penjualan } \\
\text { 6. Jumlah pelangga baru }\end{array}$ \\
\hline $8-11$ & $\begin{array}{l}\text { - Meningkatkan kualitas sistem informasi manajemen } \\
\text { - Meningkatkan kenyamanan bekerja para pekerja } \\
\text { - Mengurangi tingkat kerusakan mesin }\end{array}$ & $\begin{array}{l}\text { 7. Rasio jumlah kerusakan sarana dan } \\
\text { prasarana perusahaan } \\
\text { 8. Jumlah kerusakan mesin }\end{array}$ \\
\hline $12-14$ & $\begin{array}{ll}\text { - } & \text { Meningkatkan produktivita para pekerja } \\
\text { - } & \text { Meningkatkan loyalitas para pekerja }\end{array}$ & $\begin{array}{l}\text { 9. Tingkat produktivitas pekerja dalam } \\
\text { proses produksi } \\
\text { 10. Tingkat absensi pekerja }\end{array}$ \\
\hline $15-17$ & $\begin{array}{l}\text { - } \text { Meningkatkan efisiensi dan efektivitas produksi } \\
\text { - } \text { Mengurangi produk cacat } \\
\text { - } \text { Meningkatkan biaya operasional }\end{array}$ & $\begin{array}{l}\text { 11. Current Ratio } \\
\text { 12. Debt To Equity } \\
\text { 13. Tingkat produk cacat }\end{array}$ \\
\hline $18-20$ & - Meningkatkan kinerja keuangan & $\begin{array}{l}\text { 14. Rasio penyelesaian laporan keuangan } \\
\text { tepat waktu }\end{array}$ \\
\hline 21 & - Meningkatkan keuntungan dan pendapatan perusahaan & $\begin{array}{l}\text { 15. Tingkat pertubuhan pendapatan } \\
\text { 16. Jumlah Laba Kotor }\end{array}$ \\
\hline $22-25$ & - Meningkatkan hubungan baik dengan supplier & $\begin{array}{l}\text { 17. Rasio order mendadak } \\
\text { 18. Rasio pembatalan order } \\
\text { 19. Rasio jumlah ketepatan waktu } \\
\text { pembayaran }\end{array}$ \\
\hline $26-28$ & $\begin{array}{l}\text { - Meningkatkan kepercayaan masyarakat } \\
\text { - Menjalin hubungan baik dengan masyarakat }\end{array}$ & $\begin{array}{l}\text { 20. Jumlah siswa SMK yang PKL } \\
\text { 21. Jumlah mahasiswa yang melakukan } \\
\text { penelitian } \\
\text { 22. Jumlah tenaga kerja yang diterima } \\
\text { kerja }\end{array}$ \\
\hline
\end{tabular}

\section{Validasi Key Performance Indicator}

Validasi Key Performance Indicatosr merupakan proses verifiaksi yang dilakukan oleh perusahaan untuk menilai apakah seluruh KPI yang telah teridentifikasi sudah benar dan akurat. Validasi KPI dilakukan dengan cara memberikan kuisioner KPI kepada stakeholder perusahaan. Kemudian diperoleh hasil bahwa KPI yang teridentifikasi dapat dikatakan valid.

Dari hasil perhitungan mengunakan metode pengujian Cochran-Q, didapatkan bahwa semua key performance yang sudah diidentifikasi valid. Dari hasil validasi key performance measurement didapatkan 22 key performance Indicators.

Tabel 3. Hierarki Kinerja

\begin{tabular}{|c|c|c|c|}
\hline No & Aspek & Kriteria Kinerja & Key Performance Indicator \\
\hline \multirow{3}{*}{ A } & \multirow{3}{*}{ Input } & \multirow{3}{*}{ A.1 Meningkatkan hubungan baik dengan supplier } & A.1.1 Rasio order mendadak \\
\hline & & & A.1.2 Rasio pembatalan order \\
\hline & & & A.1.3 Rasio jumlah ketepatan waktu pembayaran \\
\hline \multirow{10}{*}{ B } & \multirow{10}{*}{ Proses } & \multirow[b]{2}{*}{ B.1 Mengurangi tingkat kerusakan mesin } & B.1.1 Rasio jumlah kerusakan sarana dan prasarana perusahaan \\
\hline & & & B.1.2 Jumlah kerusakan mesin \\
\hline & & \multirow{2}{*}{ B.2 Meningkatkan produktivitas para pekerja } & B.2.1 Tingkat produktivitas pekerja dalam proses produksi \\
\hline & & & B.2.2 Tingkat absensi pekerja \\
\hline & & \multirow[t]{3}{*}{ B.3 Meningkatkan efisiensi dan efektivitas produksi } & B.3.1 Current Ratio \\
\hline & & & B.3.2 Debt To Equity \\
\hline & & & B.3.3 Tingkat produk cacat \\
\hline & & \multirow{3}{*}{ B.4 Menjalin hubungan baik dengan masyarakat } & B.4.1 Jumlah siswa SMK yang PKL \\
\hline & & & B.4.2 Jumlah mahasiswa yang melakukan penelitian \\
\hline & & & B.4.3 Jumlah tenaga kerja yang diterima kerja \\
\hline \multirow{8}{*}{$\mathrm{C}$} & \multirow{8}{*}{ Output } & \multirow{2}{*}{ C.1 Meningkatkan kepuasan pelanggan } & C.1.1 Rasio pengiriman produk tepat waktu \\
\hline & & & C.1.2 Rasio kesalahan kuantitas pengiriman \\
\hline & & \multirow{4}{*}{ C. 2 Meningkatkan loyalitas pelanggan } & C.2.1 Jumlah komplain pelanggan \\
\hline & & & \begin{tabular}{|l|} 
C.2.2 Jumlah komplain pelanggan yang diselesaikan \\
\end{tabular} \\
\hline & & & C.2.3 Tingkat pertumbuhan penjualan \\
\hline & & & C.2.4 Jumlah pelanggan baru \\
\hline & & \multirow[t]{2}{*}{ C.3 Meningkatkan keuntungan dan pendapatan perusahaan } & C.3.1 Tingkat pertumbuhan pendapatan \\
\hline & & & C.3.2 Jumlah Laba Kotor \\
\hline
\end{tabular}




\section{Penyususnan Hierarki Kerja}

Penyusunan hierarki kerja dibuat berdasarkan kriteria stakeholder requirement. Level teratas dari hierarki adalah CV. Eka Sari dilanjutkan dengan level kriteria-kriteria stakeholder, sedangkan level berikutnya adalah KPI dari masing-masing kriteria level diatasnya.

\section{Spesifikasi Key Performance Indicator}

Setelah proses validasi selesai, maka dilakukan spesifikasi key performance indicators. Untuk setiap Key Performance Indicators yang sudah teridentifikasi kemudian dijabarkan sesuai dengan spesifikasi. Berikut ini hasil spesifikasi key performance measurement.

Tabel 4. Spesifikasi KPI Rasio Pembatalan Order

\begin{tabular}{ll}
\hline KPI & A.1.2 \\
\hline Nama KPI & Rasio Pembatalan Order \\
\hline Deskripsi & $\begin{array}{l}\text { Menunjukkan persentase dari pembatalan order kepada } \\
\text { konsumen }\end{array}$ \\
\hline Tujuan & Mengurangi adanya pembatalan order \\
\hline Target & Tidak ada pembatalan order \\
\hline Formula / Cara pengukuran & (Jumlah pembatalan order / Jumlah order) x 100\% \\
\hline Frekuensi Pengukuran & Per Bulan \\
\hline Sumber Data & Buku Daftar Pembelian Bahan \\
\hline
\end{tabular}

\section{Pembobotan Key Performance Indicator}

Pengukuran kinerja perusahaan dengan menggunakan metode Integrated Performance Measurement Systems merupakan pengukuran terintegrasi yang melibatkan Key Performance Indicators yang saling terkait satu dengan lainnya (Susetyo,2013). Pembobotan KPI pada penelitian ini menggunakan metode Analitic Hierarchy Process. Pembobotan tersebut dilakukan berdasarkan hirarki kinerja (Nurcahyanie, 2011). Alat yang digunakan untuk mengetahui bobot yaitu berupa kuisioner. Data yang diperoleh dari kuisioner kemudian diolah menggunakan Software Expert Choice. Kriteria yang memiliki nilai bobot terbesar merupakan kriteria yang harus mendapatkan perhatian yang besar dari perusahaan. Kemudian kriteria yang memiliki nilai bobot terkecil artinya kriteria tersebut belum begitu mendesak untuk ditindaklanjuti dalam rangka meningkatkan kinerja. Berikut ini hasil perhitungan bobot dari key performance indicator (Britici, 1997).

\section{Aspek Kinerja Secara Keseluruhan}

Bobot terbesar pada aspek kinerja keseluruhan yaitu pada aspek proses, hal tersebut dikarenakan proses pada perusahaan ini sangat penting karena merupkan proses mengolah bahan baku untuk menghasilkan kue, sehingga sangat berpengaruh pada hasil kue.

Tabel 5. Pembobotan Kriteria Kinerja

\begin{tabular}{|c|c|c|c|c|c|c|}
\hline $\begin{array}{l}\text { Bobot } \\
\text { Vektor }\end{array}$ & Aspek & $\begin{array}{l}\text { Bobot } \\
\text { Vektor }\end{array}$ & Kriteria Kinerja & $\begin{array}{l}\text { Bobot } \\
\text { Vektor }\end{array}$ & Key Performance Indicator & $\begin{array}{l}\text { Bobot } \\
\text { Vektor }\end{array}$ \\
\hline \multirow{21}{*}{1} & \multirow{3}{*}{ Input } & \multirow{3}{*}{0,13} & \multirow{3}{*}{ A.1 Meningkatkan hubungan baik dengan supplier } & \multirow{3}{*}{1} & A.1.1 Rasio order mendadak & 0,127 \\
\hline & & & & & A.1.2 Rasio pembatalan order & 0,104 \\
\hline & & & & & A.1.3 Rasio jumlah ketepatan waktu pembayaran & 0,769 \\
\hline & \multirow{10}{*}{ Proses } & \multirow{10}{*}{0,732} & \multirow{2}{*}{ B.1 Mengurangi tingkat kerusakan mesin } & \multirow{2}{*}{0,61} & B.1.1 Rasio jumlah kerusakan sarana dan prasarana perusahaan & 0,5 \\
\hline & & & & & B.1.2 Jumlah kerusakan mesin & 0,5 \\
\hline & & & \multirow{2}{*}{ B.2 Meningkatkan produktivitas para pekerja } & \multirow{2}{*}{0,124} & B.2.1 Tingkat produktivitas pekerja dalam proses produksi & 0,876 \\
\hline & & & & & B.2.2 Tingkat absensi pekerja & 0,124 \\
\hline & & & \multirow[t]{3}{*}{ B.3 Meningkatkan efisiensi dan efektivitas produksi } & \multirow[t]{3}{*}{0,513} & B.3.1 Current Ratio & 0,2 \\
\hline & & & & & B.3.2 Debt To Equity & 0,2 \\
\hline & & & & & B.3.3 Tingkat produk cacat & 0,6 \\
\hline & & & \multirow[t]{3}{*}{ B.4 Menjalin hubungan baik dengan masyarakat } & \multirow[t]{3}{*}{0,302} & B.4.1 Jumlah siswa SMK yang PKL & 0,143 \\
\hline & & & & & B.4.2 Jumlah mahasiswa yang melakukan penelitian & 0,143 \\
\hline & & & & & B.4.3 Jumlah tenaga kerja yang diterima kerja & 0,714 \\
\hline & \multirow{8}{*}{ Output } & \multirow{8}{*}{0,138} & \multirow{2}{*}{ C.1 Meningkatkan kepuasan pelanggan } & \multirow{2}{*}{0,54} & C.1.1 Rasio pengiriman produk tepat waktu & 0,5 \\
\hline & & & & & C.1.2 Rasio kesalahan kuantitas pengiriman & 0,5 \\
\hline & & & \multirow{4}{*}{ C.2 Meningkatkan loyalitas pelanggan } & \multirow{4}{*}{0,163} & C.2.1 Jumlah komplain pelanggan & 0,062 \\
\hline & & & & & C.2.2Jumlah komplain pelanggan yang diselesaikan & 0,486 \\
\hline & & & & & \begin{tabular}{|l|} 
C.2.3 Tingkat pertumbuhan penjualan \\
\end{tabular} & 0,353 \\
\hline & & & & & C.2.4 Jumlah pelanggan baru & 0,099 \\
\hline & & & \multirow[t]{2}{*}{ C.3 Meningkatkan keuntungan dan pendapatan perusahaan } & \multirow[t]{2}{*}{0,297} & C.3.1 Tingkat pertumbuhan pendapatan & 0,75 \\
\hline & & & & & C.3.2 Jumlah Laba Kotor & 0,25 \\
\hline
\end{tabular}




\section{Aspek Pengukuran Kinerja}

Pada aspek input terdapat kriteria kinerja yaitu meningkatkan hubungan baik dengan supplier. Bahan baku yang baik merupakan hal paling penting utnuk menghasilkan produk dengan kualitas baik. Hasil produk mempengaruhi kepuasan konsumen, jika keinginan konsumen tidak terpenuhi akan mempengaruhi terhadap loyalitas konsumen dan permintaan konsumen cenderung rendah. Pada aspek proses, bobot terbesar dimiliki oleh kriteria tujuan meningkatkan efisiensi dan efektivitas produksi. Bobot terbesar pada aspek output yaitu meningkatkan kepuasan pelanggan. Kepuasan pelanggan mempengaruhi tingkat penjualan perusahaan, karena dengan semakin meningkatnya keuasan pelaggan membuat permintaan pelanggan meningkat. Hal tersebut mempengaruhi terhadap keuntungan dan pendapatan perusahaan.

\section{Ukuran Key Performance Indicators Keseluruhan}

Untuk mengukur kinerja CV Ekasari, bobot yang digunakan adalah bobot global. Bobot global Key Performance Indicators ditunjukkan pada tabel 6.

Dari hasil pembobotan, Key Performance Indicators yang memiliki nilai bobot terbesar yaitu jumlah produk cacat. Hal ini mengindikasikan bahwa indikator produk cacat harus sangat diperhatikan. Hal tersebut didukung dengan adanya produk cacat mengakibatkan kerugian pada perusahaan, karena harus menggantikan produk cacat tersebut dengan produk baru yang harus mengeluarkan biaya lagi. Selain itu, adanya produk cacat juga mengakibatkan menurunnya kepuasan pelanggan dan banyaknya kompain pelanggan, jika produk cacat tersebut sampai kepada pelanggan.

Berdasarkan visi dan misi yang dimiliki oleh perusahaan mengindikasikan bahwa perusahaan sangat mementingkan kepuasan pelanggan. Hal ini berbeda dengan hasil dari pengukuran kinerja menggunakan IPMS yang menyatakan bahwa aspek yang paling penting untuk diperhatikan yaitu adanya produk cacat. Tingkat produk cacat merupakan KPI dari kriteria kinerja meningkatkan efisiensi dan efektivitas produksi. Perbedaan tersebut dikarenakan oleh pembagian responden kuisioner yang kurang merata, dimana sebagian besar responden merupakan stakeholder internal perusahaan. Hal tersebut menyebabkan hasil pembobotan yang paling tinggi yaitu pada aspek internal perusahaan.

Tabel 6. Peringkat Bobot Global Key Performance Indicators

\begin{tabular}{|l|c|}
\hline \multicolumn{1}{|c|}{ Key Performance Indicator } & Bobot Global \\
\hline A.1.1 Rasio order mendadak & 0,017 \\
\hline A.1.2 Rasio pembatalan order & 0,014 \\
\hline A.1.3 Rasio jumlah ketepatan waktu pembayaran & 0,100 \\
\hline B.1.1 Rasio jumlah kerusakan sarana dan prasarana perusahaan & 0,223 \\
\hline B.1.2 Jumlah kerusakan mesin & 0,223 \\
\hline B.2.1 Tingkat produktivitas pekerja dalam proses produksi & 0,080 \\
\hline B.2.2 Tingkat absensi pekerja & 0,011 \\
\hline B.3.1 Current Ratio & 0,075 \\
\hline B.3.2 Debt To Equity & 0,075 \\
\hline B.3.3 Tingkat produk cacat & 0,225 \\
\hline B.4.1 Jumlah siswa SMK yang PKL & 0,032 \\
\hline B.4.2 Jumlah mahasiswa yang melakukan penelitian & 0,032 \\
\hline B.4.3 Jumlah tenaga kerja yang diterima kerja & 0,158 \\
\hline C.1.1 Rasio pengiriman produk tepat waktu & 0,037 \\
\hline C.1.2 Rasio kesalahan kuantitas pengiriman & 0,037 \\
\hline C.2.1 Jumlah komplain pelanggan & 0,001 \\
\hline C.2.2 Jumlah komplain pelanggan yang diselesaikan & 0,011 \\
\hline C.2.3 Tingkat pertumbuhan penjualan & 0,008 \\
\hline C.2.4 Jumlah pelanggan baru & 0,002 \\
\hline C.3.1 Tingkat pertumbuhan pendapatan & 0,031 \\
\hline C.3.2 Jumlah Laba Kotor & 0,010 \\
\hline
\end{tabular}




\section{Kesimpulan}

Terdapat 22 Key Performance Indicators pada perusahan katering CV Ekasari dengan kriteria kinerja yaitu meningkatkan hubungan baik dengan supplier, mengurangi tingkat kerusakan mesin, meningkatkan produktivitas para pekerja, meningkatkan efisiensi dan efektivitas produksi, menjalin hubungan baik dengan masyarakat, meningkatkan kepuasan pelanggan, meningkatkan loyalitas pelanggan, meningkatkan keuntungan dan pendapatan perusahaan. Dari hasil pembobotan, didapatkan aspek yang harus diperhatikan yaitu aspek proses, kemudian kriteria kinerja yang harus lebih diperhatikan yaitu meningkatkan kepuasan pelanggan, dan Key Performance Indicators yang harus sangat diperhatikan adalah jumlah produk cacat.

\section{DAFTAR PUSTAKA}

Averson, Paul. (1998). The Deming Cycle. The Balanced Scorecard Institute.

Bode, S. (2003). Successful Catering: Managing the Catering Operation for Maximum Profit, Atlantic.

Bourgeois, R. (2005). Analytical Hierarchy Process: an Overview, UNCAPSA-UNESCAP. Bogor.

Britici, U. dan Cerrie., McDeviti. (1997). Integrated Performance Measurement System: a development guide, International Journal of Operation and Production Management. Vol. 17 No. 5.

Nurcahyanie. (2011). Perancangan Sistem Pengukuran Kinerja Dengan Metode Integrated Performance Measurement Systems (IPMS). Jurnal Teknik Waktu. Vol 09 No 01. Pp. 1412-1867.

Susetyo, J. (2013). Penerapan Sistem Pengukuran Kinerja Perusahaan Dengan Metode Integrated Performance Measurement System (IPMS) Pada PT. X. Jurnal Teknologi, volume 6 Nomor 1, pp. 2013, 98-107.

Winarni., Purnomo. (2012). Pengukuran Kinerja Perusahaan Dengan Metode Integrated Performance Measurement Systems (IPMS). Prosiding Seminar Nasional Aplikasi Sains \& Teknologi (SNAST). pp. 185-194.

Witjaksono. (2009). Perancangan Sistem Pengukuran Kinerja Di Apotek Xyz Dengan Menggunakan Metode Integrated Performance Measurement Systems (Ipms) Dan Pembobotan Triangular Fuzzy AHP. Skripsi. Surakarta: Teknik Industri, Universitas Sebelas Maret.

Zabidi, Yasrin. (2008). Performance Measurement System : Peranannya dalam Menghadapi dan Memenangkan Persaingan Global. http://www.YAZA@Consultant.com. Diakses tanggal 2 November 2008 . 